\title{
HealthAffairs
}

At the Intersection of Health, Health Care and Policy

Cite this article as:

Jon R. Gabel, Heidi Whitmore, Jeremy Pickreign, Jennifer L. Satorius and Sam Stromberg

Small Employer Perspectives On The Affordable Care Act's Premiums, SHOP

Exchanges, And Self-Insurance

Health Affairs, , no. (2013):

doi: 10.1377/hlthaff.2013.0861

The online version of this article, along with updated information and services, is available at:

http://content.healthaffairs.org/content/early/2013/10/15/hlthaff.2013.0861.full.html

For Reprints, Links \& Permissions:

http://healthaffairs.org/1340_reprints.php

E-mail Alerts : http://content.healthaffairs.org/subscriptions/etoc.dtl

To Subscribe: http://content.healthaffairs.org/subscriptions/online.shtml

Health Affairs is published monthly by Project HOPE at 7500 Old Georgetown Road, Suite 600, Bethesda, MD 20814-6133. Copyright ( 2013 by Project HOPE - The People-to-People Health Foundation. As provided by United States copyright law (Title 17, U.S. Code), no part of Health Affairs may be reproduced, displayed, or transmitted in any form or by any means, electronic or mechanical, including photocopying or by information storage or retrieval systems, without prior written permission from the Publisher. All rights reserved.

Advance online articles have been peer reviewed and accepted for publication but have not yet appeared in the paper journal (edited, typeset versions may be posted when available prior to final publication). Advance online articles are citable and establish publication priority; they are indexed by PubMed from initial publication. Citations to Advance online articles must include the digital object identifier (DOIs) and date of initial publication.

Not for commercial use or unauthorized distribution 


\section{Small Employer Perspectives On The Affordable Care Act's Premiums, SHOP Exchanges, And Self-Insurance}

ABSTRACT Beginning January 1, 2014, small businesses having no more than fifty full-time-equivalent workers will be able to obtain health insurance for their employees through Small Business Health Options Program (SHOP) exchanges in every state. Although the Affordable Care Act intended the exchanges to make the purchasing of insurance more attractive and affordable to small businesses, it is not yet known how they will respond to the exchanges. Based on a telephone survey of 604 randomly selected private firms having 3-50 employees, we found that both firms that offered health coverage and those that did not rated most features of SHOP exchanges highly but were also very price sensitive. More than 92 percent of nonoffering small firms said that if they were to offer coverage, it would be "very" or "somewhat" important to them that premium costs be less than they are today. Eighty percent of offering firms use brokers who commonly perform functions of benefit managers-functions that the SHOP exchanges may assume. Twenty-six percent of firms using brokers reported discussing self-insuring with their brokers. An increase in the number of self-insured small employers could pose a threat to SHOP exchanges and other small-group insurance reforms.

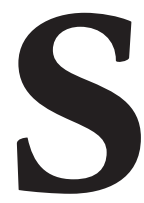

mall employers are generally defined as firms with three to fifty full-timeequivalent workers. In the United States more than 2.9 million small firms employ about 29.5 million workers, or about 25.4 percent of employed Americans. These firms could obtain health insurance coverage for their employees in the small-group insurance market. ${ }^{1}$

It is generally recognized that the small-group market does not perform as well for its customers as the insurance markets for midsize and large groups do for theirs. ${ }^{2}$ There are a variety of reasons for the worse performance of the small-group market, including its higher administrative costs, rigorous medical underwriting (because coverage availability and premium costs are tied to the health status of a smaller number of employees), volatile pricing (with premium costs that can vary substantially from year to year), and the offering of lower-value products (in which premiums are high relative to the financial protection that they provide). Competition among insurers in the small-group market depends heavily on insurers' skill in medical underwriting-a logical consequence of spreading catastrophic costs among a few employees in a small firm.

To improve the performance of the smallgroup market, the Affordable Care Act made multiple changes in the rules for the insurance marketplace. An overarching aim of these reforms is to alter the small-group market so that insurers in it no longer compete on skill in medical un-
Jon R. Gabel (Gabel-Jon@ NORC.org) is senior fellow at NORC at the University of Chicago, in Bethesda, Maryland.

Heidi Whitmore is a senior research scientist at NORC at the University of Chicago, in Dayton, Minnesota.

Jeremy Pickreign is a senior statistician at NORC at the University of Chicago, in Albany, New York.

Jennifer L. Satorius is a senior research analyst at NORC at the University of Chicago, in Chicago, Illinois.

Sam Stromberg is a research analyst at NORC at the University of Chicago, in Bethesda. 
derwriting but on price and quality. Policy makers anticipated that a reformed market would improve access to insurance, better control the growth in the cost of coverage, and improve the quality of care.

The Affordable Care Act's small-group reforms are too numerous to list here. Some of the major ones are the establishment of the Small Business Health Options Program (SHOP) exchanges; an end to medical underwriting based on an individual's health status; and the setting of premiums based only on "community rating," in which costs can vary only by an individual's age, geography, family size, and whether or not he or she smokes. There are also tax credits for companies with high percentages of low-income workers; state-defined essential health benefits required of qualified health plans-those plans permitted to offer coverage in the SHOP exchanges; a requirement that to qualify, plans have an actuarial value of at least 0.6 , meaning that the plans must pay out at least 60 percent of covered expenses; and pooling of small-group plans so that pricing and medical loss ratios (the portion of premium dollars spent on medical care) are done in the aggregate rather than for separate plans.

As of October 1, 2013, companies with fifty or fewer full-time-equivalent employees began signing up for insurance coverage through the SHOP exchange in their state. Seventeen states and the District of Columbia are operating their own SHOP exchanges, and the remaining exchanges are being administered by the Department of Health and Human Services. Coverage takes effect January 1, 2014.

SHOP exchanges are electronic marketplaces where company managers can obtain information on each qualified health plan sold in the exchange-including its benefits, premiums, networks, and actuarial value-and sign their company up for the plan of their choice. SHOP exchanges will perform administrative functions such as aggregating bills, participating in claims adjudication, and answering questions from consumers. Employers will make a fixed contribution for each employee according to the cost of the base plan and tier-or level of coverage-that the employer selects.

In the "employer model" used by the federally run exchange, the employer chooses one plan, and all employees who take up coverage through the firm are enrolled in that plan. The "employee model" used by seventeen of the eighteen statebased exchanges has many variations. One common element is that if an employee chooses a higher-cost plan than the base plan selected by the employer, the employee pays the difference in premiums out of pocket. $^{3}$

Although many of the provisions of the
Affordable Care Act are intended to make it easier for small businesses to obtain health insurance coverage for their employees, it is not yet clear how these companies will respond to the exchanges. To get a better idea of their interests and expectations, we first examine the state of the small-group market in 2013, the last year prior to the act's near-full implementation. Second, we assess the attributes of health insurance and features associated with the SHOP exchanges that do and do not appeal to small employers. Third, we examine the impact on small employers of aspects of the health care law that are already in effect.

\section{Study Data And Methods}

From January through June 2013, National Research LLP conducted telephone interviews with benefit managers of private US firms with three to fifty employees. Thirty-seven percent of the respondents were CEOs, 33 percent office managers, 4 percent executives responsible for human resources, and 7 percent chief financial officers; 19 percent had some other position. The sample frame, obtained from Dun and Bradstreet, was randomly selected and stratified by firm size, with additional controls for industry and geographic location. Of the 604 firms whose representatives completed interviews, 434 companies already offered health benefits, and 170 companies did not.

The survey instrument included questions for nonoffering firms on why they did not purchase coverage, their experience shopping for it, and what would make them more likely to purchase it. Offering firms were asked about their purchasing experience, factors that would improve their shopping experience, their views about selected attributes of the exchanges, how the health care law had affected them thus far, and whether they had considered self-insurance.

All of our analyses used statistical weights based on the inverse of the probability that the firm would be selected for the survey; this is the firm's employer weight. Employee-based weights were the product of the number of workers in the firm and the firm's employer weight. Two additional weights-eligibility-based weight and coverage-based weight-were the products of the employee-based weight and the proportions of eligible and covered workers in the firm, respectively. Most of the statistics presented in this article used employer weights.

When calculating standard errors, we use the statistical software SAS Callable SUDAAN, version 9.2, to adjust for design effects. Differences presented in the text are significant at the 0.05 level. 
Study Results

cost AND coverage The average monthly premium for a single policy among small employers was slightly more than $\$ 502$ per month, or about $\$ 6,029$ per year, in 2013. Premiums were lowest for firms in the South; highest for companies with 10-24 workers; and-compared to companies with few low-income workers-lower for firms having larger proportions of younger, lower-income ( $\$ 50,000$ or less per year), and male workers.

Sixty percent of all small firms offered coverage in 2013 (Exhibit 1). Specifically, the shares were 53 percent for firms with 3-9 workers, 72 percent for firms with 10-24 workers, and 82 percent for firms with $25-50$ workers. In contrast, 93 percent of all employers with 51 or more workers offered coverage. ${ }^{4}$ Eighty-one percent of workers at small firms offering coverage were employed in firms that provided coverage for dependents. And among small firms offering coverage, 3 percent offered limited-benefit plans, also called mini-med plans. These plans typically have a low cap on the annual dollar value of covered services.

For offering and nonoffering small firms, only 57 percent of employees were eligible for coverage, and 41 percent obtained coverage from their employer (Exhibit 1). Some employees not covered by their employer's plan probably obtained coverage from a spouse's plan or from a public source such as Medicaid. Among small firms that offered health benefits, 72 percent of employees took up some coverage. Firms with more than 50 workers had significantly higher take-up rates. Similarly, midsize and large firms were significantly more likely than small firms to cover part-time workers.

VIEWS AND HISTORY OF NONOFFERING FIRMS When asked to choose "the most important reason why your firm does not currently offer health insurance to your employees," 75 percent of respondents chose the answer "cost of health insurance is too high," and 15 percent chose the answer "employees are generally covered under another plan." Only 0.4 percent of respondents at nonoffering firms said that their employees had no interest in health benefits. Ten percent of nonoffering firms had offered coverage within the past five years.

When respondents at nonoffering firms were asked what monthly premium for single coverage the firm could afford, they identified price points (that is, maximum prices that the firm would consider paying) considerably below the current market average of $\$ 502$. Twenty-two percent of respondents indicated that their firm could afford $\$ 300$ or more per month, and 15 percent said \$200-\$300. Fifty-six percent re-

\section{EXHIBIT 1}

Differences In Coverage In Plans For Small Groups And For Midsize And Large Groups, 2013

\begin{tabular}{|c|c|c|}
\hline & $\begin{array}{l}\text { Small } \\
\text { groups }\end{array}$ & $\begin{array}{l}\text { Midsize and } \\
\text { large groups }\end{array}$ \\
\hline \multicolumn{3}{|l|}{ AMONG OFFERING AND NONOFFERING FIRMS, PERCENT OF: } \\
\hline $\begin{array}{l}\text { Firms offering coverage } \\
\text { Employees eligible for coverage } \\
\text { Employees covered by employer's plan }\end{array}$ & $\begin{array}{l}60.1 \\
56.6 \\
41.0\end{array}$ & $\begin{array}{l}93.3^{* * *} \\
74.8^{* \cdots+} \\
60.5^{* * *}\end{array}$ \\
\hline \multicolumn{3}{|l|}{ AMONG OFFERING FIRMS, PERCENT OF: } \\
\hline $\begin{array}{l}\text { Employees eligible for coverage } \\
\text { Employees taking up coverage } \\
\text { Employees covered by employer's health plan } \\
\text { Employers offering coverage to part-time employees } \\
\text { Employees working for a firm offering dependent coverage } \\
\text { Employers offering more than one plan }\end{array}$ & $\begin{array}{l}81.1 \\
72.4 \\
58.7 \\
17.2 \\
80.9 \\
23.1\end{array}$ & $\begin{array}{l}76.0 \cdots \\
80.9 \cdots \\
61.5 \\
34.2^{\cdots *} \\
\overline{3}^{\mathrm{a}} \\
31.5\end{array}$ \\
\hline
\end{tabular}

Source Authors' analysis of data from: (1) Commonwealth Fund/NORC 2013 Survey of Small Employers; and (2) Kaiser Family Foundation and Health Research and Educational Trust. Employer health benefits: 2013 annual survey (Note 4 in text). Notes A small group is a firm with 3-50 workers. Midsize and large groups are firms with more than 51 workers. Average monthly premiums for single coverage were $\$ 502$ for small groups and \$494 for midsize and large groups in 2013. ${ }^{2}$ The Kaiser Family Foundation and Health Research and Educational Trust do not collect these data. ${ }^{\mathrm{b}}$ The Kaiser Family Foundation and Health Research and Educational Trust do not collect these data. Therefore, this percentage of employers offering more than one plan should be regarded as the minimum percentage of employers offering more than one plan. Given this difference, no statistical testing was conducted. ${ }^{* *} p<0.05$

sponded they could not afford monthly premiums of $\$ 200$, and the remainder responded "don't know." Our survey data indicate that in the current small-group market, only 18 percent of plans cost less than $\$ 300$ per month.

PURCHASING DECISIONS OF NONOFFERING FIRMs Thirty-seven percent of nonoffering firms reported having shopped for an insurance plan within the past five years. Firms in the East and Midwest were more likely to have shopped than those in the South and West.

We asked respondents from all small nonoffering firms, "How important would each of the following items be for your firm to consider offering health insurance?" Exhibit 2 displays the percentages of firms answering "very" or "somewhat important" and shows how closely purchasing decisions are linked to the cost of health insurance. For example, 82 percent of respondents said it would be "very important" "if health insurance cost less than it does today."

ROLE OF BROKERS FOR OFFERING FIRMS Insurance agents and brokers play major roles in small employers' purchasing decisions, often serving as de facto benefit managers. Eighty percent of offering firms use a broker or agent, and firms with 25-50 employees are more likely to use one than are firms with fewer workers. Small firms that use brokers have them perform various tasks: 84 percent use brokers to select a health plan, 79 percent to enroll employees, 59 percent to provide customer services such 
EXHIBIT 2

Importance Of Various Items To Small Nonoffering Firms When Considering Whether To Offer Insurance, 2013

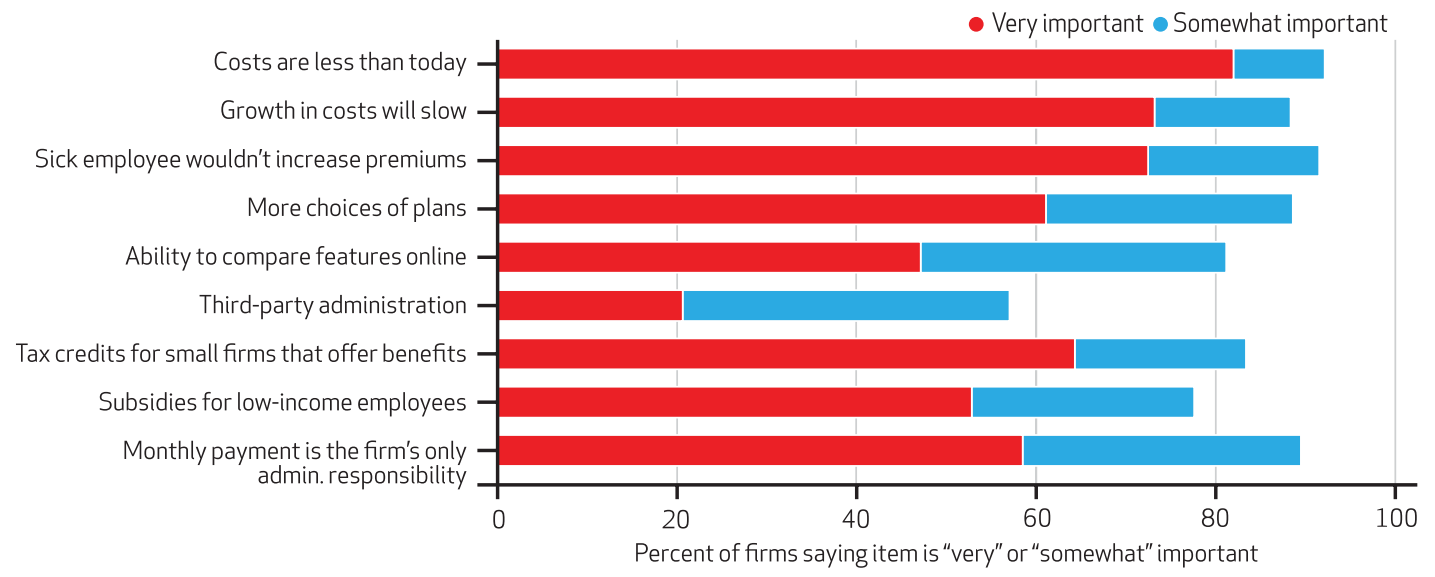

SOURCE Commonwealth Fund/NORC 2013 Survey of Small Employers.

as appealing denied claims, 57 percent to administer benefits through COBRA (the Consolidated Omnibus Budget Reconciliation Act of 1986), and 31 percent to determine employees' contributions toward premiums.

THE SHOPPING EXPERIENCE We asked small employers that offered a health plan, had offered a plan in the past five years, or had shopped for a plan in the past five years about the difficulty of different aspects of their shopping experience (Exhibit 3). Fifty-six percent responded that finding an affordable plan was "very difficult," and 26 percent said that it was "somewhat difficult." Employers found comparing premiums less difficult than other tasks, but 38 percent reported that even that comparison was "very" or "somewhat" difficult.

We asked small firms offering coverage, "How important would each of the following items be in making the process of providing health bene- fits easier, less expensive, and a better value?" (Exhibit 4). The most highly rated item was "ability to compare plans by cost, benefits, physicians in the network, and other features," which was rated "very important" by 68 percent of respondents.

APPEAL OF SELECTED SHOP FEATURES We asked small employers that offered coverage about their interest in a number of features that the SHOP exchanges will have and about various scenarios that could occur if they used a SHOP exchange. The survey questions did not specifically mention SHOP exchanges, instead describing their characteristics broadly.

Fifty-six percent of respondents said that they were more interested in "offering workers a choice of plans, with the employer paying a fixed amount, and the employee paying any extra cost for choosing a more expensive plan" (the "employee model") than in "offering workers one

\section{EXHIBIT 3}

Difficulty Of Various Aspects Of Shopping For Benefits, Among Small Firms That Offer Benefits Or Bought Or Shopped For Benefits In The Past Five Years, 2013

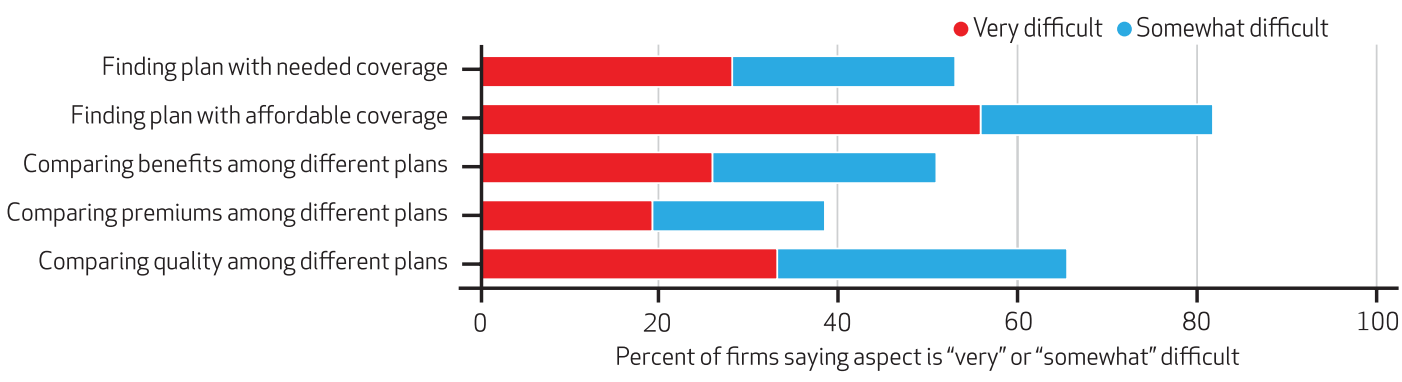

Source Commonwealth Fund/NORC 2013 Survey of Small Employers. 
Small Offering Firms' Views On The Importance Of Various Items For Improving Health Benefits, 2013

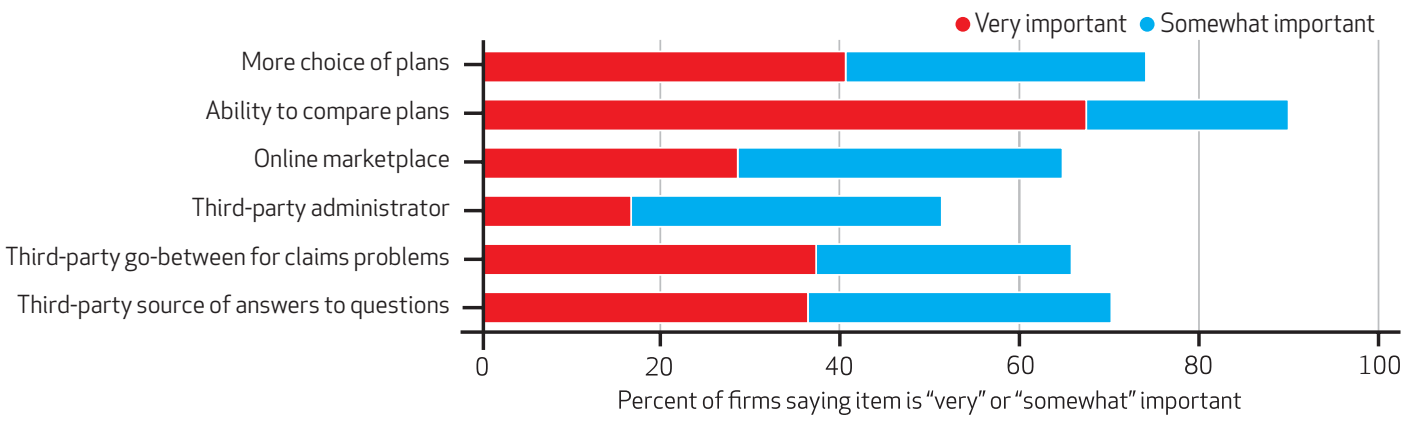

source Commonwealth Fund/NORC 2013 Survey of Small Employers.

plan with less administrative work for your firm" (the "employer model"). Thirty-six percent preferred the employer model. In a related question, respondents were asked about their interest in the following scenario: Employees would be offered a choice of plans, with no change in cost to the firm, which would pay a fixed amount. Twenty-two percent said they would be very interested, and 45 percent would be somewhat interested.

When asked what is more important to their firm and its employees, being able to buy coverage from the dominant carrier in the state or having a "broader" (more extensive) choice of plans, 66 percent of respondents said that broader choice mattered more.

Small employers showed an interest in narrow-network plans, if using such plans would reduce costs. The survey defined narrow-network plans as those contracting with 25 percent of the doctors and hospitals in the community. If using a narrow network instead of a broad networkone with 80 percent of the doctors and hospitals in the community-would lower premiums by 5 percent, 57 percent of the respondents said they would opt for the narrow network. If the premiums were 10 percent lower, 77 percent would choose the narrow network, and with 20 percent lower premiums, 82 percent would do so.

One feature of the SHOP exchanges that has broad appeal is "getting one bill and writing one check each month." Seventy percent of employers indicated they would be "very interested" in such an approach.

If dental, vision, and other benefits such as disability insurance were part of an online marketplace, a sizable segment of small employers expressed interest in shopping for them. Thirtytwo percent indicated they would be "very interested," and 36 percent would be "somewhat in- terested." Twenty-two percent said they would be "very interested" in shopping for wellness benefits through an online marketplace, but 40 percent would be "somewhat interested."

\section{Impact On Small Employers To Date} Although most of the provisions of the Affordable Care Act take effect in 2014, the law has already affected many small employers in a number of ways. Half of all small firms were aware of provisions offering tax credits for small employers with substantial numbers of lowerincome workers (those earning $\$ 50,000$ or less per year). Small firms with large numbers of lower-income workers were no more likely to be aware of the tax credits than were small firms with fewer lower-income workers.

About one in six nonoffering firms that were aware of the tax credit considered offering health insurance because of it. Among all small firms that were aware of the tax credit, 61 percent had determined whether or not they were eligible for it. Firms with a relatively high percentage of older workers (those age fifty or older) were more likely than others to have made such a determination.

When asked if the firm's insurer had changed its benefit package because of the Affordable Care Act, 44 percent of employers said yes, 22 percent said no, and 34 percent said they didn't know. In fact, provisions that went into effect in 2010-such as prohibiting lifetime maximum benefits and requiring coverage of adult children up to age twenty-fix-have affected all plans.

Seventeen percent of small employers reported receiving a rebate from insurers. Seventy percent said they had not received one, and 13 percent were unable to answer the question. These rebates are a result of the medical loss ratio 


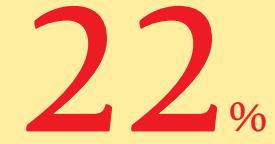

Covered an adult child As a result of the Affordable Care Act, 22 percent of small employers offering coverage reported having at least one adult child enrolled in their plan who would not have been eligible before health reform. review provisions in the health care law. The medical loss ratio is the average portion of earned premiums an insurance company spends on medical benefits and quality improvements, as opposed to administrative activities. Under the law, in the small-group market this portion must be at least 80 percent, and an insurer must give its subscribers a rebate for the difference should its medical loss ratio fall below that level.

As a result of Affordable Care Act provisions, 22 percent of small employers offering coverage reported having at least one adult child (up to age twenty-six) enrolled in their health plan who would not have been eligible before health reform. On average, these firms covered two adult children. Based on survey findings, an estimated 725,000 adult children were covered by small employers because of the act.

\section{Self-Insurance}

An unintended consequence of the Affordable Care Act is that it may make self-insurance attractive for small firms. Even prior to health reform, there were many advantages to selfinsurance. For example, self-insured plans were not subject to state-mandated benefits, state premium taxes, consumer protections, reserve requirements, and other state regulatory requirements. An employer with a young and healthy workforce could have lower premiums with selfinsurance than with coverage obtained as part of a pool of employers. Currently, only 8 percent of firms with 3-50 workers self-insure..$^{5}$

The major drawback to self-insuring has been the financial risk of having a covered person experience a catastrophic illness or injury, and the subsequent substantial increase in the cost for stop-loss coverage that would ensue. Stoploss coverage is a form of reinsurance that limits the amount of money that employers must pay out for a claim or group of claims.

But self-insurance may become more attractive as the Affordable Care Act takes effect. Because the act eliminates medical underwriting, if one or more insured workers or dependents at a small firm were to incur catastrophic costs in a given year, the next year the firm could move into the fully insured community-rated market on or off the SHOP exchange.

We asked small employers using brokers if their brokers had discussed with them the possibility of self-insurance, and 26 percent said yes. (Firms with relatively older workers were more likely to respond positively, as were firms with relatively more high-earning workers.) For firms not using brokers, only 1 percent considered selfinsuring. Among firms whose brokers had discussed self-insuring, or firms not using brokers

\section{One clear message from employers is that the cost of coverage is by far the most important factor in their purchasing decisions.}

but considering self-insuring, 9 percent said they were "very likely" to self-insure, and 14 percent were "somewhat likely." In all, roughly 5 percent of small firms offering coverage are either "very" or "somewhat likely" to move from full to selfinsurance in the next few years.

\section{Discussion}

This survey of 604 small employers provides information on the current state of the small-group market during the year before the SHOP exchanges become operational. We found that just 57 percent of employees were eligible for coverage through their employer, and only 41 percent of employees obtained that coverage (Exhibit 1). The cost of a single policy now exceeds $\$ 6,000$ a year-about 42 percent of the pretax earnings of a minimum-wage worker working full time.

The Affordable Care Act has already affected many small employers. Sixteen percent of them have received rebates from their insurers, and 725,000 adult children are covered by their parents' policies who would not have been eligible before the act's passage. About half of employers were aware of tax credits for small employers, and 60 percent of them had determined whether or not they were eligible for the credits.

The survey findings also provide information on aspects of the SHOP exchanges that may and may not appeal to small employers. One clear message from employers is that the cost of coverage is by far the most important factor in their purchasing decisions. The majority of employers not offering coverage identified price points (the highest premium amount they would consider) that were substantially lower than prices in the current market.

However, a sizable segment of nonoffering firms are close to purchasing health benefits: Nearly one-fourth of these firms reported price 


\section{The exchanges must obtain a strong buy-in from brokers while demonstrating superior value over what already exists in the small-group market.}

points that were in the range of current plan prices. If tax credits were factored into the price of coverage, a larger segment of nonoffering small employers would have price points within that range. Moreover, 37 percent of nonoffering firms have shopped for coverage in the past five years.

Employers displayed their price sensitivity in other ways. Eighty-two percent of nonoffering firms indicated that it would be "very important" in their decision to buy health insurance for their workers if costs were lower than they are today. A majority of employers offering coverage were willing to select a plan with a narrow network of providers instead of one with a broad network if by doing so they could save 5 percent of their costs. If they could save 20 percent, 82 percent would select the narrow-network plan.

Many facets of the SHOP exchanges were very appealing to small employers. The most attractive feature was "getting one bill and writing one check each month." Seventy percent of small employers said they would be "very interested" in such an arrangement. About two-thirds believed that the process of offering health benefits would be "easier, less expensive, and better value" if they could compare costs, benefits, and physicians in networks among plan offerings. Substantial percentages of employers indicated that it would be "very important" to have a greater choice of plans than they do now and to have a third party that would act as a go-between in handling claims disputes.

Interestingly, having an online marketplace was not so highly rated. This may reflect the late Steve Jobs's observation that "customers don't know what they want until we've shown them."

Small employers showed strong preferences for the "employee model" over the "employer model," even if the former involved higher administrative expenses than the latter. As noted above, seventeen of the eighteen state-based SHOP exchanges have chosen the employee model. ${ }^{7}$ However, federally run exchanges will not offer that model until 2015.

\section{Conclusion}

We conclude by identifying two formidable challenges facing the SHOP exchanges. First, as states and the federal government implement them, it is imperative that the exchanges obtain a strong buy-in from brokers while simultaneously demonstrating superior value over what already exists in the small-group market.

Eighty percent of small employers use brokers, and these brokers perform most of the functions of a benefit manager, including selecting a plan, enrolling employees, and handling disputes over claims. The SHOP exchanges will perform many of the same functions, and with superior technology and economies of scale they will be able to do so at a lower cost than brokers can offer. This would suggest that brokers' fees would be reduced, leading brokers to oppose the exchanges. Historically, without broker buy-in, small-group exchanges tend not to succeed. ${ }^{8}$

Second, the survey quantified a muchdiscussed unintended consequence of the Affordable Care Act: a movement to self-insurance, which poses a threat not just to SHOP exchanges but to the entire small-group market. Under the act, self-insured firms do not have the same plan design requirements as fully insured firms. For example, self-insured plans do not have to meet essential benefit requirements of their state. Consequently, some brokers have suggested to small employers that they self-insure and purchase stop-loss coverage at attachment points as low as $\$ 10,000$. (Attachment points are the dollar amount where stop-loss insurance begins paying for medical expenses.)

Moreover, should a small firm self-insure and incur catastrophic costs, instead of facing prohibitive stop-loss premiums the following year, it could simply move into the fully insured market through a SHOP exchange, where premiums are community rated (with adjustments for age of the workforce and geographic location). Among firms using a broker, 26 percent reported that their broker had already discussed the possibility of self-insuring in 2014.

Our calculations based on survey data suggest that 5 percent of firms are "very likely" and 7 percent "somewhat likely" to move from selfinsured to fully insured status in "the next few years." These figures may underestimate the likely growth of self-insurance. After a few years of 
converting to self-insurance, the small-group market could reach a tipping point that would leave the fully insured markets with greater risks, higher premiums, and eventually a socalled death spiral-in which costs become prohibitive for most people, so few people enroll except the sick, making per enrollee costs even higher. Based on the Urban Institute's Health Insurance Policy Simulation Model, without regulation of the stop-loss coverage market, the differences in premiums for fully and selfinsured firms might reach 25 percent for single and 19 percent for family policies. ${ }^{9}$

To prevent this potential erosion of insurance, states need to reform their stop-loss markets so that stop-loss coverage is not de facto health insurance. Alternatively, if and when Congress is ready to make technical improvements in the Affordable Care Act, it should prohibit the sale of stop-loss coverage to small firms. If a tipping point were reached, then the many appealing features of the SHOP exchanges would be lost, and the small-group market would revert to the risk-based market it was prior to health reform.
The authors thank the Commonwealth Fund for the financial support (Grant No. 20110556) that made this work possible. The authors especially acknowledge the contributions of Sara Collins, whose ideas greatly shaped the study. The authors thank Tim Jost, Terry Gardiner, and Jon Kingsdale for their contributions to the questionnaire, and Tracy Garber for her assistance throughout the project. [Published online October 16, 2013].

\section{NOTES}

1 The average number of workers per firm is from the survey whose results we report here. The number of firms with 3-50 workers is derived from Dun and Bradstreet's electronic database of businesses in the United States.

2 James J. Health Policy Brief: Small business insurance exchanges. Health Affairs [serial on the Internet]. 2012 Feb 9 [cited 2013 Sep 20]. Available from: http://www .healthaffairs.org/healthpolicy briefs/brief.php?brief_id=62

3 Kingsdale J. How small-business health exchanges can offer value to their future customers-and why they must. Health Aff (Millwood). 2012;31(2):275-83.

4 Kaiser Family Foundation, Health
Research and Educational Trust. Employer health benefits: 2013 annual survey [Internet]. Menlo Park (CA): KFF; 2013 [cited 2013 Oct 8]. Section 2:37. Available from: http:// kaiserfamilyfoundation.files.word press.com/2013/08/8465-employerhealth-benefits-20131.pdf

5 Authors' calculation from Kaiser Family Foundation and Health Research and Educational Trust 2013 survey data (see Note 4).

6 Quoted in: Isaacson W. Steve Jobs. New York (NY): Simon and Schuster; 2011. p. 328-9.

7 Dash S, Lucia KW, Keith K, Monahan C. Implementing the Affordable Care Act: key design decisions for statebased exchanges. New York (NY): Commonwealth Fund. 2013 Jul.
8 Gardiner T. Health insurance exchanges of past and present offer examples of features that could attract small-business customers. Health Aff (Millwood). 2012;31(2): 284-9.

9 Buettgens M, Blumberg LJ (Urban Institute, Washington, DC). Small firm self-insurance under the Affordable Care Act [Internet]. New York (NY): Commonwealth Fund; 2012 Nov [cited 2013 Sep 23]. (Issue Brief). Available from: http://www .commonwealthfund.org/ /media/ Files/Publications/Issue\%20Brief/ 2012/Nov/1647_Buettgens_small_ firm_self_insurance_under_ACA_ ib.pdf 